\title{
Clinical features and the course of psoriasis in children
}

\author{
Cechy obrazu klinicznego i przebieg łuszczycy u dzieci
}

Vasyl Yevtykhiiovych Tkach, Marian Stefanovych Voloshynovych, Galyna Yevgenivna Girnyk, Nataliia Valeriivna Kozak
Chair of Dermatology and Venereology, Ivano-Frankivsk National Medical University, Ivano-Frankivsk, Ukraine
Dermatol Rev/Przegl Dermatol 2020, I07, 476-480
DOI: https://doi.org//0.5 I I 4/dr.2020. 101677

Psoriasis is a chronic multisystemic disease with predominant skin involvement. In the human population its prevalence reaches $3-5 \%$. Psoriasis is one of the most frequent diseases among chronic dermatoses and reaches 12-15\% [1-4]. Statistical data on psoriasis in Ukraine are significantly different from the average in Europe and the world, as the prevalence of the disease has steadily increased over the last decades - from 114.8 per 100 thousand people in 1994 to 222.5 per 100 thousand in 2014 including over 6,000 children [5,6]. According to official statistics, the largest number of psoriasis patients is in the Carpathian region, so we consider our data to be representative of a much larger region than just the western part of Ukraine.

Psoriasis occurs at any age. There are two peaks of the onset of the disease at aged 20-30 and 50-60 years [7]. Psoriasis also occurs at a much younger age; its onset is observed in early childhood. According to literature data, psoriasis is the second most common disease after atopic dermatitis in children. The risk of this disease in boys and girls is the same. Psoriasis is more common in children over 10 years of age, but episodes also occur in early childhood [8-10]. This disease is an idiopathic one, but the role of the genetic component is certain. The implementation of genetic conditioning can be at any age. The main causes of psoriasis are stress, infections, immunological processes, diseases of the internal organs, nervous and endocrine system, traumas, medications, etc. Possible causes of psoriasis morbidity in children are psychoemotional overload, social problems and household troubles, ecological pollution, and reduction of immune reactivity $[9,11,12]$.

This study aimed at investigating the frequency, clinical features and the course of psoriasis in children under 6 years old.

For over 40 years, we have monitored the incidence and clinical course of psoriatic disease in infants. The study materials were case histories, outpatient cards, and counseling logs. The focus was on the onset of the disease, the causes, the family history, clinical manifestations, the effectiveness of therapy, and the duration of remission. The patients were ex-
Łuszczyca jest przewlekłą chorobą wieloukładową, w przebiegu której zmiany dotyczą głównie skóry. Częstość jej występowania w populacji ogólnej szacuje się na 3-5\%. Łuszczyca jest również jedną z najczęstszych (12-15\%) przewlekłych dermatoz [1-4]. Dane statystyczne dotyczące łuszczycy na Ukrainie znacznie odbiegają od wartości średnich w Europie i na świecie, ponieważ częstość występowania tej choroby systematycznie wzrasta w ostatnich dziesięcioleciach - ze 114,8 na 100 tys. osób w 1994 r. do 222,5 na 100 tys. osób w 2014 r. (w tym ponad 6 tys. dzieci) [5, 6]. Według oficjalnych statystyk najwięcej chorych na łuszczycę zamieszkuje ukraiński region Karpat. Dlatego uważamy, że nasze dane są reprezentatywne dla znacznie większego obszaru niż tylko zachodnia część Ukrainy.

Łuszczyca może wystąpić w każdym wieku, jednak obserwuje się dwa szczyty zachorowań - pierwszy między 20. i 30. rokiem życia i drugi między 50. i 60. rokiem życia [7]. Zauważalny jest coraz młodszy wiek zachorowań, a przypadki łuszczycy są obserwowane nawet we wczesnym dzieciństwie. Zgodnie z dostępnymi danymi z literatury łuszczyca jest drugim co do częstości występowania schorzeniem dermatologicznym u dzieci (po atopowym zapaleniu skóry). Ryzyko zachorowania jest takie samo u obu płci. Łuszczyca występuje częściej u dzieci w wieku powyżej 10 lat, ale epizody zdarzają się także we wczesnym dzieciństwie [8-10]. Choroba ma charakter idiopatyczny, jednak wskazuje się, że istotną rolę w jej rozwoju odgrywa podłoże genetyczne. Uwarunkowania genetyczne mogą się ujawniać w każdym wieku. Do głównych bezpośrednich przyczyn łuszczycy należą: stres, przebyte zakażenia, procesy immunologiczne, choroby narządów wewnętrznych, układu nerwowego i endokrynnego, urazy, przyjmowane leki. U dzieci zachorowanie na łuszczycę może być również spowodowane obciążeniem psychoemocjonalnym, problemami w otoczeniu społecznym i domowym, skażeniem środowiska, a także zmniejszeniem reaktywności immunologicznej $[9,11,12]$.

W niniejszej pracy analizowano częstość występowania, obraz kliniczny i przebieg łuszczycy u dzieci poniżej 6. roku życia.

W analizie uwzględniono dane dotyczące zachorowalności i przebiegu klinicznego łuszczycy u najmłod- 
amined: general blood test, analysis of feces for worm eggs, blood proteins, lipids, cholesterol, bilirubin, blood sugar, immunogram (test demonstrates the strength and activity of immune system [analysis of cellular and humoral immune activity, complement systems and phagocytosis]), alanine aminotransferase (ALT), aspartate aminotransferase (AST), and ultrasound of the abdominal organs. In the case of detection of somatic pathology, patients were consulted by specialists. Patients were distributed by age. The first group comprised children of early childhood (from birth to 3 years), and the second group comprised children of preschool age (from 3 to 6 years).

The study was approved by Local Bioethical Committee of Ivano-Frankivsk Regional Clinical Dermatological and Venereological Dispensary, decision No. 01.1-12/160 of 30.12.2015.

We observed 112 children, among them up to 1 year - 14 (12.5\%) people, from 1 year to 3 years - 36 (32.14\%), from 3 to 6 years $-62(55.36 \%)$. The youngest patient was 2 weeks of age. The literature available to us reports on, described for the first time in 1899 by Rille, psoriasis in a 6-day-old infant. There are cases where children were born with psoriasis [13].

Interesting data show a significant increase in the number of patients with psoriasis in infants and preschool children, among our first identified psoriasis. In the first 10 years (1978-1987) only 6 patients $(5.36 \%)$ were registered, and in the second decade (1988-1997) the number of patients increased threefold - $18(16.07 \%)$ people, in the third (1998-2007) $37(33.03 \%)$, in the last (2008-2017) - $42(37.5 \%)$, and in $2018-9(8.04 \%)$ children (fig. 1).

It was discovered that $68(60.71 \%)$ children were burdened family history of psoriasis. For instance, in $35(31.25 \%)$ patients, the occurrence of the lesions was caused by stressful situations, mainly in children of the second group; in $54(48.21 \%)$ patients lesions were preceded by infectious diseases such as angina, SARS, influenza, chicken pox, and scarlet fever. Seven $(6.25 \%)$ patients psoriasis occurred following worm infestation, in $3(2.68 \%)$ patients after preventive vaccinations, and in $13(11.6 \%)$ patients the cause of psoriasis was not clear.

The children we observed had, as a rule, a mild course of psoriasis; only $2(1.78 \%)$ patients had erythroderma provoked by excessive insolation (fig. 2). One 6-year-old girl developed psoriatic arthropathy and onychodystrophy. More than $59 \%$ of patients had a widespread rash, while in the rest it was limited. In common psoriasis droplet and lenticular exudative red papules with clear borders and silvery scales predominated. The rash was localized more often on the trunk, scalp, folds, upper and lower extremities. In $11(9.82 \%)$ patients psoriasis manifested on the face (fig. 3). Compared with adults, papules were rarely szych dzieci w okresie 40 lat. Jako materiał badawczy wykorzystano wywiady medyczne, karty pacjentów i dzienniki porad. $W$ analizie skupiono się na czasie wystąpienia choroby, przyczynach, wywiadzie rodzinnym, obrazie klinicznym, skuteczności leczenia oraz czasie trwania remisji. U pacjentów została wykonana morfologia krwi, badanie kału w kierunku obecności jaj pasożytów, proteinogram, lipidogram, oznaczenie stężenia cholesterolu i bilirubiny, glukozy we krwi, immunogram, oznaczenia aminotransferazy alaninowej (ALT) i asparaginianowej (AST), a także badanie USG narządów jamy brzusznej. W przypadku zaburzeń somatycznych chorzy byli konsultowani przez specjalistów. Pacjentów podzielono według wieku: pierwsza grupa obejmowała dzieci w najmłodszym wieku (od urodzenia do 3. roku życia), a druga grupa - dzieci w wieku przedszkolnym (3-6 lat).

Badanie zostało zatwierdzone przez Lokalną Komisję Bioetyczną Regionalnej Klinicznej Poradni Dermatologicznej i Wenerologicznej w Iwano-Frankowsku decyzją nr 01.1-12/160 z dnia 30.12.2015 r.

Analizowano chorobę u łacznie 112 dzieci, w tym 14 poniżej 1. roku życia (12,5\%), $36 \mathrm{w}$ wieku od roku do 3 lat $(32,14 \%)$ oraz $62 \mathrm{w}$ wieku 3-6 lat (55,36\%). Wiek najmłodszego pacjenta ujętego $\mathrm{w}$ analizie wynosił 2 tygodnie. W piśmiennictwie można znaleźć opis przypadku łuszczycy u 6-dniowego noworodka opublikowany w 1899 r. przez Rillego. Opisywano również przypadki dzieci urodzonych z łuszczycą [13].

Ciekawe są dane pokazujące znamienny wzrost liczby przypadków łuszczycy u dzieci najmłodszych oraz $\mathrm{u}$ dzieci w wieku przedszkolnym w analizowanym czasie w stosunku do pierwszych zidentyfikowanych przypadków łuszczycy. W pierwszej dekadzie (lata 19781987) odnotowano zaledwie 6 przypadków (5,36\%), ale w drugiej (lata 1988-1997) ta liczba się potroiła $18(16,07 \%)$. W trzeciej dekadzie (lata 1998-2007) zarejestrowanych było 37 (33,03\%) przypadków, a w ostatnim analizowanym dziesięcioleciu (lata 2008-2017) 42 (37,5\%) przypadki. W 2018 r. było 9 (8,04\%) przypadków (ryc. 1).

U 68 (60,71\%) dzieci stwierdzono obciążający wywiad rodzinny w kierunku łuszczycy. U 35 (31,25\%) pacjentów czynnikiem wywołującym zmiany były sytuacje stresowe - dotyczyło to głównie dzieci z drugiej grupy. U 54 $(48,21 \%)$ pacjentów wystąpienie łuszczycy poprzedzały choroby zakaźne, takie jak angina, SARS, grypa, ospa wietrzna i szkarlatyna. U 7 (6,25\%) pacjentów łuszczyca wystąpiła w związku z zakażeniem pasożytami jelitowymi, a u $3(2,68 \%)$ - po szczepieniach profilaktycznych. U 13 (11,6\%) pacjentów przyczyny łuszczycy nie udało się jednoznacznie ustalić.

U dzieci objętych obserwacją przebieg łuszczycy był $\mathrm{z}$ reguły łagodny. U zaledwie $2(1,78 \%)$ pacjentów wystąpiła erytrodermia wywołana nadmiernym nasłonecznieniem (ryc. 2). U jednej pacjentki: 6-letniej dziewczynki, 


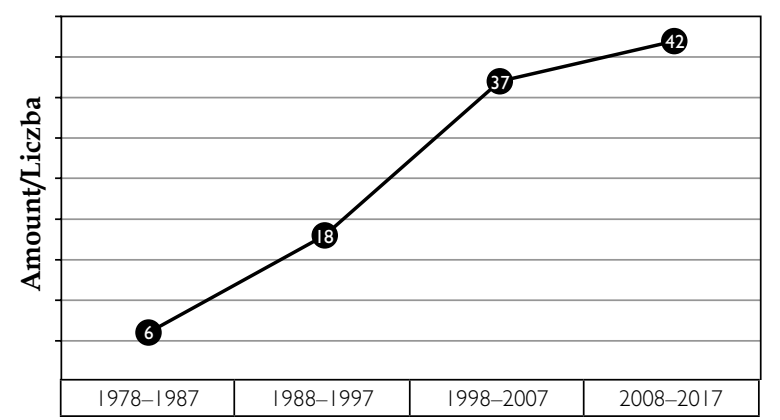

Years/Lata

Figure I. Incidence of psoriasis in children (1978-2017)

Rycina I. Częstość występowania łuszczycy u dzieci (lata 19782017)

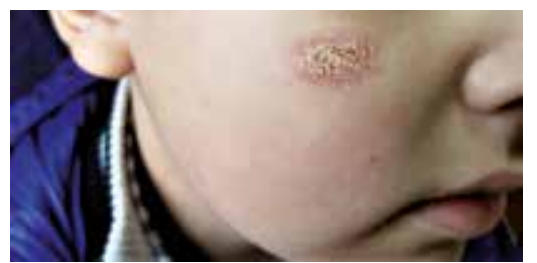

Figure 3. Psoriasis manifested on the face

Rycina 3. Zmiany łuszczycowe umiejscowione na twarzy

present on the elbows and knees, and only in $6.25 \%$ on the palms and soles. In infants and children up to 3 years of age (first group), more limited forms with localization in the axillary and inguinal folds, scalp, large pubic lips, and scalp were more common. Rash was present in the form of bright red plaques with weeping surface, covered with gray-yellow crusts and scales, localized on the scalp, often occipital and frontal areas. The plaques were covered with a thick layer of scales imitating asbestos seborrhea. However, on the edge of the plaques a red crown was visible (fig. 4). As a rule, when the scalp was affected, psoriatic elements were also located behind the auricles
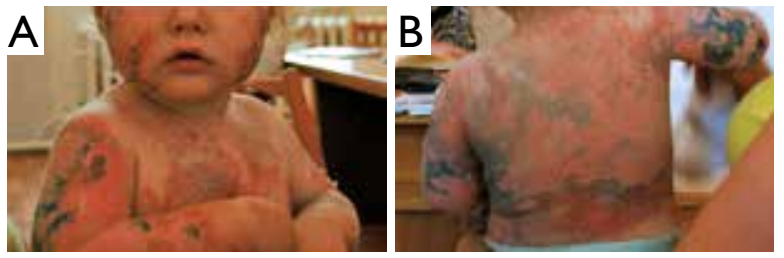

Figure 2. Children with psoriatic erythroderma

Rycina 2. Dzieci z erytrodermią łuszczycową

rozpoznano łuszczycowe zapalenie stawów i onychodystrofię. U ponad 59\% pacjentów zmiany skórne były rozległe, a u pozostałych miały charakter ograniczony. W łuszczycy zwykłej przeważały wykwity grudkowe o wyraźnych granicach, pokryte srebrzystą łuską. Zmiany skórne występowały typowo na tułowiu, owłosionej skórze głowy, w fałdach skórnych, a także na skórze kończyn górnych i dolnych. U 11 (9,82\%) pacjentów zmiany łuszczycowe pojawiały się w obrębie twarzy (ryc. 3). W przeciwieństwie do pacjentów dorosłych rzadko były umiejscowione na łokciach i kolanach. Oprócz tego jedynie w 6,25\% przypadków wykwity występowały na powierzchniach dłoniowych i podeszwowych. U niemowląt i dzieci do 3. roku życia (pierwsza grupa) częściej stwierdzano bardziej ograniczone postacie choroby, z lokalizacją w fałdach pachowych i pachwinowych, na owłosionej skórze głowy i wargach sromowych większych. Zmiany skórne miały postać żywoczerwonych blaszek o sączącej powierzchni, pokrytych szarożółtymi strupami i łuską, umiejscowionych na owłosionej skórze głowy, często w okolicy potylicznej i czołowej. Blaszki łuszczycowe były pokryte grubą warstwą łuski przypominającej łupież azbestowy. Wokół blaszek widoczna była czerwona obwódka (ryc. 4). W przypadku zajęcia owłosionej skóry głowy zmiany łuszczycowe były zazwyczaj umiejscowione również za małżowinami usznymi oraz w zewnętrznych kanałach słuchowych. Miały
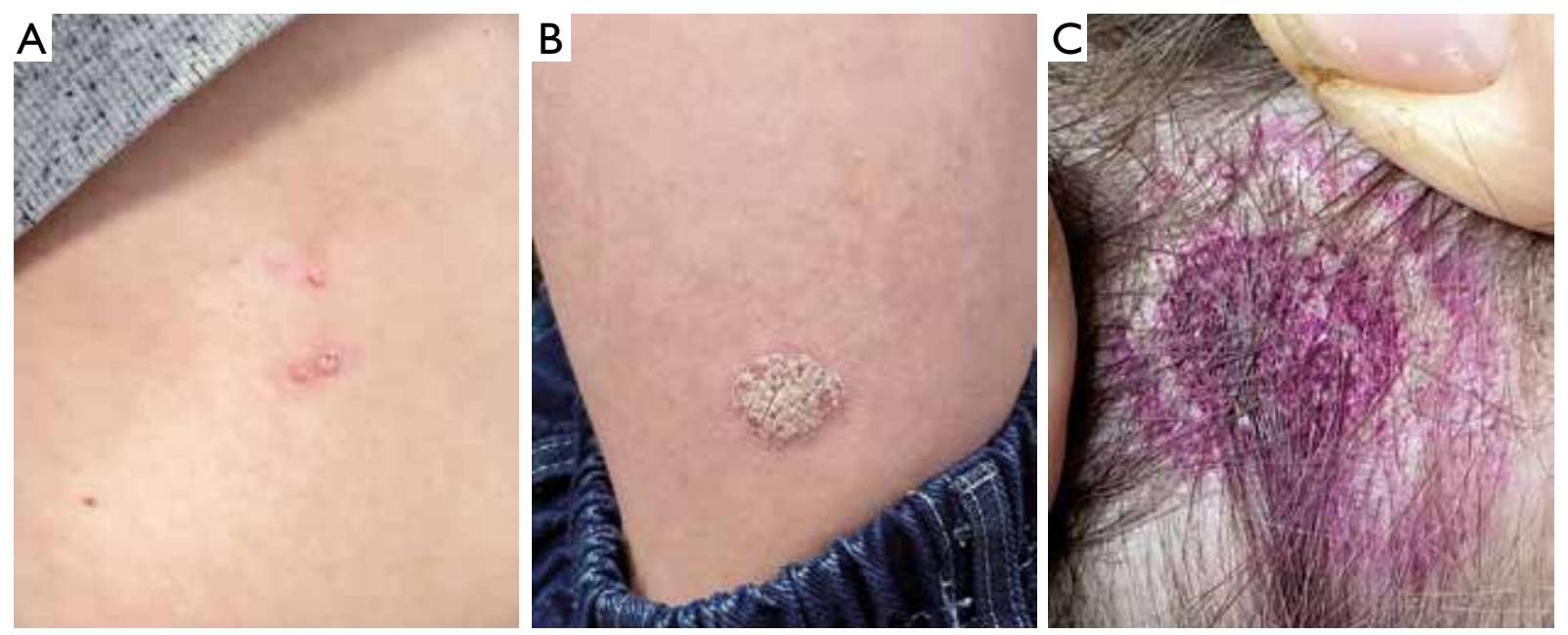

Figure 4. Different localization of focal psoriasis

Rycina 4. Inna lokalizacja łuszczycy ogniskowej 
and in the external auditory passages. They were exudative in nature, often with a weeping surface looking like impetigo.

As for the second age group (from 3 to 6 years), among 62 patients in 16 patients $(25.8 \%)$, we noticed atypical localization of psoriasis, namely in the upper and lower eyelids (psoriatic blepharitis). The elements of rash were characterized by slight edema of the eyelids and small, not intensive scaling. These patients have been treated by ophthalmologists for a long time. Psoriasis was diagnosed only after the appearance of single papules on the trunk, extremities, in the area of the navel and behind the ears.

A distinctive feature of psoriasis clinics in infants and preschool children was the more permanent, pronounced and lasting Koebner phenomenon. The psoriatic triad was often incomplete, owing to the indistinct stearin stain.

Subjective sensations, as a rule, were absent; only in the case of localization in folds, in genitals, on the scalp and in external ear passages were the patients disturbed by slight itching. In 7 (6.25\%) children with helminth infestation the itching was severe, as evidenced by the excoriations on the psoriatic lesions.

Blood tests revealed nonspecific inflammatory changes, in patients with concomitant helminthiasis - eosinophilia. Decrease in blood absolute number of T-lymphocytes, increase of the content of immune complexes. In 43 (39.39\%) patients with signs of obesity in blood plasma, there was an increase in total lipids, triglycerides, phospholipids and cholesterol. Also, $2.67 \%$ of children had an increase in blood sugar; as a result, an endocrinologist diagnosed type 1 diabetes.

Ultrasound examination of abdominal organs in 12 children of the second group (19.35\%) revealed dyskinesia of the biliary tract, in 7 - pyelonephritis $(6.25 \%)$.

Treatment of patients was conducted taking into account the stage and severity of the disease. In patients with severe forms of psoriasis systemic treatment was applied. Patients with mild disease received topical treatment only. The food for children was rich in vitamins, and had a minimal amount of carbohydrates and fats. All the children were under observation the dispensary. During the dispensary period, preventive examinations were carried out, rehabilitation of the foci of infection, feces were investigated for the presence of helminth infestation, and conversations with parents regarding the prevention of stressful situations in everyday life and at school were conducted. In most cases remission ranged from 3 to 12 months. The prognosis for recovery, as in adults, was unfavorable. Relapses are possible after stress, nervous overstrain and transmitted infectious diseases.

The data from our observations indicate an increase in the incidence of psoriasis in early childhood and preschool age. Most patients had inherited psoriasis. charakter wysiękowy, często z sączącą powierzchnią przypominającą liszajec.

W drugiej grupie wiekowej (3-6 lat) u 16 (25,8\%) z 62 pacjentów stwierdzono nietypową lokalizację zmian łuszczycowych na powiekach górnych i dolnych (łuszczycowe zapalenie brzegów powiek). Zmiany charakteryzowały się nieznacznym obrzękiem powiek oraz słabo nasiloną łuską. Pacjenci ci byli leczeni okulistycznie przez długi okres, a łuszczycę rozpoznano dopiero po pojawieniu się pojedynczych zmian grudkowych na tułowiu, kończynach, w okolicy pępka i za uszami.

Charakterystyczną cechą obrazu klinicznego zarówno u dzieci w wieku najmłodszym, jak i przedszkolnym, był utrzymujący się nasilony objaw Koebnera. Klasyczna triada objawów łuszczycowych była często niepełna ze względu na brak nasilonego objawu świecy stearynowej.

Zazwyczaj nie występowały objawy subiektywne. Jedynie w przypadku umiejscowienia zmian łuszczycowych w fałdach skórnych, w obrębie narządów płciowych, na owłosionej skórze głowy oraz w zewnętrznych przewodach usznych pacjenci zgłaszali lekki świąd. U 7 (6,25\%) dzieci z zakażeniem pasożytami jelitowymi świąd był nasilony, o czym świadczyła obecność przeczosów na zmianach skórnych.

W badaniach krwi stwierdzono nieswoiste zmiany zapalne, a u pacjentów ze współistniejącą robaczycą również eozynofilię. Immunogram przedstawiał zmniejszenie bezwzględnej liczby limfocytów T we krwi oraz wzrost zawartości kompleksów immunologicznych. U 43 (39,39\%) pacjentów z otyłością stwierdzono podwyższone całkowite stężenie lipidów, triglicerydów, fosfolipidów i cholesterolu w surowicy. Ponadto u 2,67\% dzieci wykazano podwyższone stężenie glukozy we krwi, a rozpoznano cukrzycę typu 1.

W badaniu ultrasonograficznym narządów jamy brzusznej u 12 (19,35\%) dzieci z drugiej grupy stwierdzono dyskinezę dróg żółciowych, a u 7 (6,25\%) odmiedniczkowe zapalenie nerek.

Leczenie pacjentów prowadzono z uwzględnieniem stopnia i nasilenia zaawansowania choroby. U chorych z ciężkimi postaciami łuszczycy zastosowano leczenie ogólne. Pacjenci z łagodną chorobą byli leczeni tylko miejscowo. Dieta dzieci była bogata w witaminy, o minimalnej zawartości węglowodanów i tłuszczów. Wszystkie dzieci były pod obserwacją ambulatoryjną. W tym czasie wykonywano badania profilaktyczne i leczono ogniska zakażenia. Badano również kał na obecność pasożytów oraz prowadzono rozmowy z rodzicami dotyczące zapobiegania stresującym sytuacjom w życiu codziennym i szkolnym. W większości przypadków okres remisji wynosił 3-12 miesięcy. Rokowanie co do wyleczenia podobnie jak u pacjentów dorosłych było niekorzystne. Nawroty choroby mogą pojawiać się $\mathrm{W}$ reakcji na stres, przeciążenie nerwowe oraz przebyte choroby zakaźne. 
The combination of hereditary and provocative factors was the main cause of the onset of psoriatic disease.

Additionally, stress and infectious diseases were the most frequent trigger factors. A characteristic feature was the predominance in the clinical picture of droplet and lenticular exudative papules. Notably, in infants the rash was localized mainly in the folds in the form of plaques with a wet surface, often with signs of weeping. Finally, in most children, Koebner's symptom is pronounced and long-lasting, and the psoriatic triad is incomplete, which is caused by the anatomical and physiological features of the skin in early childhood and preschool age.

\section{CONFLICT OF INTEREST}

The authors declare no conflict of interest.
Dane z naszych obserwacji wskazują na wzrost zachorowalności na łuszczycę we wczesnym dzieciństwie i wieku przedszkolnym. U większości pacjentów łuszczyca miała charakter dziedziczny. Główną przyczyną wystąpienia choroby było połączenie komponentu dziedzicznego z czynnikami prowokacyjnymi.

Do najczęstszych czynników bezpośrednio wyzwalających chorobę należały stres i przebyte choroby zakaźne. Cechą charakterystyczną była przewaga w obrazie klinicznym wysiękowych grudek. Warto zaznaczyć, że u najmłodszych dzieci zmiany były zlokalizowane głównie w fałdach skórnych i miały postać blaszek o wilgotnej powierzchni. Ponadto u większości dzieci utrzymywał się nasilony objaw Koebnera i często nie występowały wszystkie składowe klasycznej triady objawów. Jest to spowodowane anatomicznymi i fizjologicznymi uwarunkowaniami dotyczącymi skóry we wczesnym dzieciństwie i wieku przedszkolnym.

\section{KONFLIKT INTERESÓW}

Autorzy nie zgłaszają konfliktu interesów.

\section{References \\ Piśmiennictwo}

1. Parisi R., Symmons D.P.M., Griffiths C.E.M., Ashcroft D.M.: Global epidemiology of psoriasis: a systematic review of incidence and prevalence. J Invest Dermatol 2013, 133, 377-385.

2. Michalek I.M., Loring B., John S.M.: A systematic review of worldwide epidemiology of psoriasis. J Eur Acad Dermatol Venereol 2017, 31, 205-212.

3. Griffiths C.E.M., van der Walt J.M., Ashcroft D.M., Flohr C., Naldi L., Nijsten T., et al.: The global state of psoriasis disease epidemiology: a workshop report. Br J Dermatol 2017, 177, e4-e7.

4. Bolotna L.A.: Psoriasis: the choice of optimal topical corticosteroid drug. Ukr J Dermatol Venerol Cosmetol $2019,73,55-62$.

5. Stepanenko R.L., Alkammaz A.M., Stepanenko V.I.: Rational stage hormonal and nonhormonal local therapy of psoriasis. Ukr J Dermatol Venerol Cosmetol 2018, 70, 31-38.

6. Stepanenko R.L., Konovalova T.S.: Influence of immunobiological therapy on microwashing the psoriatic process. Ukr J Dermatol Venerol Cosmetol 2019, 72, 7-16.

7. Henseler T., Christophers E.: Psoriasis of early and late onset: characterization of two types of psoriasis vulgaris. J Am Acad Dermatol 1985, 13, 450-456.

8. Augustin M., Glaeske G., Radtke M.A., Christophers E., Reich K., Schäfer I.: Epidemiology and comorbidity of psoriasis in children. Br J Dermatol 2010, 162, 633-636.

9. Bronckers I.M.G.J., Paller A.S., van Geel M.J., van de Kerkhof P.C.M., Seyger M.M.B.: Psoriasis in children and adolescents: diagnosis, management and comorbidities. Pediatr Drugs 2015, 17, 373-384.

10. Raychaudhuri S.P., Gross J.: A comparative study of pediatric onset psoriasis with adult onset psoriasis. Pediatr Dermatol 2000, 17, 174-178.

11. Tollefson M.M., Crowson C.S., McEvoy M.T., Maradit Kremers H.: Incidence of psoriasis in children: a population-based study. J Am Acad Dermatol 2010, 62, 979-987.

12. Tollefson M.M., Van Houten H.K., Asante D., Yao X., Kremers H.M.: Association of psoriasis with comorbidity development in children with psoriasis. JAMA Dermatol 2018, 154, 286-292.

13. Nyfors A., Lemholt K.: Psoriasis in children. Br J Dermatol 1975, 92, 437-442.

Received: 27.12.2019

Accepted: 14.08.2020

Otrzymano: 27.12 .2019 r.

Zaakceptowano: 14.08.2020 r.

How to cite this article

Yevtykhiiovych Tkach V., Stefanovych Voloshynovych M., Yevgenivna Girnyk G., Valeriivna Kozak N.: Clinical features and the course of psoriasis in children. Dermatol Rev/Przegl Dermatol 2020, 107, 476-480. DOI: https://doi.org/10.5114/dr.2020.101677. 